\title{
MANAJEMEN SARANA DAN PRASARANA DI SMK N 1 KASIHAN BANTUL
}

\author{
Putri Isnaeni Kurniawati, Suminto A. Sayuti \\ PPs UNY, Universitas Negeri Yogyakarta \\ puspu_18@yahoo.co.id
}

\begin{abstract}
Abstrak
Penelitian ini bertujuan untuk mengetahui manajemen sarana dan prasarana yang digunakan dan mendeskripsikan proses pengadaan, pemeliharaan dan penghapusan sarana dan prasarana di SMK N 1 Kasihan, Bantul. Penelitian ini menggunakan pendekatan kualitatif dan metode survey. Teknik pengumpulan data yang digunakan adalah observasi, wawancara, dan studi dokumentasi. Hasil penelitian menunjukkan sebagai berikut. Manajemen sarana dan prasarana yang digunakan oleh SMK N 1 Kasihan khususnya pada mata pelajaran produktif adalah manajemen standar. Pengadaan sarana dan prasarana dilakukan setiap akhir tahun dengan menganalisis kebutuhan-kebutuhan yang diperlukan dengan menetapkan perencanaan untuk jangka satu semester atau satu tahun ke depan dengan memperhatikan dana yang dimiliki. Pemeliharaan sarana dan prasarana sekolah, dilakukan dengan pemeliharaan sehari-hari, pemeliharaan secara berkala, dan pemeliharaan yang sifatnya mencegah dari kerusakan. Penghapusan sarana dan prasarana sekolah, sampai saat ini belum pernah melakukan penghapusan barang.
\end{abstract}

Kata kunci: manajemen, sarana dan prasarana

\section{THE MANAGEMENT OF FACILITIES AND INFRASTRUCTURE IN SMK N 1 KASIHAN BANTUL \\ Abstract}

This research aims to reveal the management of facilities and infrastructure and to describe the process of procurement, maintenance, and abolishment of facilities and infrastructure at SMK N 1 Kasihan, Bantul. This research used the qualitative approach and survey method. The data were collected through observation, interviews, and documentary study. The result of the research shows the following. The management of facilities and infrastructure at SMK N 1 Kasihan, particularly productive subjects, is the standardized management. The infrastructure procurement is conducted every year end by analyzing the needs which are required by determining the plans for one semester or one year ahead with regard to the funds. The maintenance of the school facilities and infrastructure is through daily maintenance, regular maintenance, and maintenance which prevents the damage. The abolishment of goods has never been done,

Keywords: management, infrastructure and fasilities 


\section{Pendahuluan}

Pendidikan kejuruan merupakan bagian dari sistem pendidikan yang mempersiapkan seseorang agar mampu bekerja pada satu kelompok pekerjaan atau satu bidang pekerjaan dari pada bidang-bidang pekerjaan. Untuk mencapai tujuan tersebut, pendidikan kejuruan harus mengembangkan program pengajarannya melalui analisis jabatan pekerjaan yang diperlukan peserta didik. Pendidikan kejuruan adalah pendidikan yang mempersiapkan peserta didiknya untuk memasuki lapangan kerja serta mengembangkan sikap profesional sebagai tenaga kerja tingkat menengah pada usaha dan industri/dunia kerja. Dengan demikian bentuk program-program pendidikan di Sekolah Menengah Kejuruan (SMK) harus disesuaikan dengan jenisjenis pekerjaan yang ada di lapangan kerja.

Sekolah Menengah Kejuruan sebagai pendidikan menengah kejuruan merupakan salah satu subsistem dari sistem Pendidikan Nasional yang memainkan peran sangat strategis bagi terwujudnya tenaga kerja terampil nasional. Hal ini sesuai dengan tujuan Sekolah Menengah Kejuruan yaitu meningkatkan kecerdasan, pengetahuan, kepribadian, akhlak mulia, serta keterampilan untuk hidup mandiri, dan mengikuti pendidikan lebih lanjut sesuai dengan kejuruannya (PP No. 19 Tahun 2005 pasal 26 ayat 3). Sekolah Me-nengah Kejuruan memiliki peran yang sangat strategis dalam menyiapkan sumber daya manusia. Guna menghadapi tantangan di era globalisasi, maka minimal kompetensi yang harus dimiliki lulusan SMK adalah penguasaan teori, kemampuan praktek, sikap kerja, kompetensi personal dan kompetensi sosial (Zamtinah, 2000, p.209).

Oleh karena itu, tenaga kerja Indonesia harus memiliki karakteristik kualitas sumber daya manusia sebagai kompetensi kunci yang sangat dibutuhkan dalam memperebutkan pekerjaan yang diberikan dalam bentuk program-program pendidikan di Sekolah Menengah Kejuruan. Untuk itu, proses pembelajaran di Sekolah Menengah Kejuruan wajib memberikan peserta didiknya pengetahuan dan keterampilan sesuai dengan tuntunan dunia kerja. Departemen Pendidikan Nasional melalui Direktorat Pembinaan SMK telah membuat Rencana Strategis (Renstra) 20102014, yang berisi kerangka dan arah "pengembangan pendidikan kejuruan yang membangun manusia yang berjiwa kreatif, inovatif, sportif dan wirausaha". Usaha tersebut dilakukan untuk meningkatkan penyelenggaraan proses belajar mengajar agar lebih baik, efektif dan efisien (Garis-garis Besar Program Pembinaan SMK Tahun 2012).

Permasalahan yang muncul dari usaha di atas adalah adanya dilema, di satu sisi menuntut Sekolah Menengah Kejuruan tanggap terhadap tuntutan dunia kerja, namun di sisi lain Sekolah Menengah Kejuruan menuntut biaya investasi yang besar, karena Sekolah Menengah Kejuruan membutuhkan fasilitas praktik berupa gedung, mesin-mesin, peralatan dan fasilitas pendukung praktik lainnya serta biaya operasional yang tinggi. Keberhasilan program pendidikan di Sekolah Menengah Kejuruan melalui proses belajar mengajar dipengaruhi oleh banyak faktor, salah satu di antaranya adalah tersedianya sarana dan prasarana pendidikan untuk menunjang proses pembelajaran yang teratur dan berkelanjutan (PP No. 19 Tahun 2005 pasal 42 ayat 1 dan 2 ).

Sarana dan prasarana pendidikan merupakan salah satu faktor pendidikan yang keberadaannya sangat mutlak dalam proses pendidikan. Ary H. Gunawan (2002, p.116) menyatakan bahwa kegiatan administrasi sarana dan prasarana pendidikan meliputi: "perencanaan, prakualifikasi, pengadaan, penyimpanan, pemeliharaan, penghapusan dan pengendalian". Fakta di lapangan ternyata masih ditemui berbagai persoalan pengelolaan sarana dan prasarana pendidikan di Sekolah Menengah Kejuruan yakni para guru belum dapat mengelola sarana dan prasarana pendidikan sesuai praktek dan teorinya.

Persoalan pengelolaan sarana dan prasarana pendidikan di Sekolah Menengah Kejuruan tersebut juga dialami oleh 
SMK N 1 Kasihan Bantul yang merupakan salah satu Sekolah Menengah Kejuruan pada bidang kompetensi kelompok seni yang bertujuan meningkatkan sumber daya manusia untuk menghasilkan tamatan yang mandiri dan profesional dalam bidang seni pertunjukan sesuai dengan program keahlian masing-masing dan meningkatkan kinerja sekolah untuk menghasilkan tamatan yang berkualitas, kreatif di bidang seni pertunjukan guna memenuhi kebutuhan tenaga kerja seni pertunjukkan di era globalisasi yang sesuai dengan visi dan misi sekolah tersebut.

SMK N 1 Kasihan memiliki empat program keahlian, yaitu: (1) Seni Karawitan; (2) Seni Tari; (3) Seni Theater; dan (4) Seni Pedalangan. Untuk mencapai standar kompetensi yang telah ditetapkan oleh industri/dunia usaha/asosiasi profesi, struktur kurikulum SMK N 1 Kasihan mengelompokkan dan mengorganisasikan menjadi mata pelajaran normatif, adaptif dan produktif. Kualitas lulusan sangat dipengaruhi oleh struktur kurikulum yang ada, tetapi mata pelajaran produktif sangat berperan pada kualitas lulusan karena berfungsi membekali peserta didik agar memiliki kompetensi kerja sesuai Standar Kompetensi Kerja Nasional Indonesia (SKKNI). Dalam mata pelajaran produktif dengan empat program keahlian di SMK N 1 Kasihan, masing-masing program keahlian membutuhkan sarana dan prasarana pendidikan.

Persoalan pengelolaan sarana dan prasarana pendidikan di SMK N 1 Kasihan, kondisi sarana dan prasarana pendidikan yang kurang terpelihara, kurangnya pemanfaatan sarana dan prasarana pendidikan, tidak semua guru mau menggunakan sarana dan prasarana pendidikan, kurang tersedianya ruang untuk menyimpan sarana prasarana dan minimnya keberadaan sarana dan prasarana pendidikan di sekolah. Untuk mengatasi persoalan sarana prasarana di SMK N 1 Kasihan dan tercapainya tujuan beserta sasaran sarana prasarana pendidikan mata pelajaran produktif pada masing-masing program keahlian di SMK N 1 Kasihan, maka perlu suatu manajemen atau pengelolaan sarana dan prasarana pendidikan.

Manajemen sarana dan prasarana pendidikan khususnya mata pelajaran produktif meliputi: pengadaan, pemeliharaan, dan penghapusan. Manajemen sarana dan prasarana pendidikan sangat berpengaruh dalam peningkatan kualitas pembelajaran guna mendukung tercapainya mutu pendidikan di SMK N 1 Kasihan dan menjadi hal yang essensial untuk diteliti.

\section{Manajemen Pendidikan}

Manajemen mengandung arti semua kegiatan yang diselenggarakan oleh seseorang atau lebih, dalam suatu kelompok atau organisasi/lembaga untuk mencapai tujuan organisasi/lembaga yang telah ditetapkan. Terry (1977, p.4) menyebutkan: "management is a distinct process consisting of planning, organizing, actuating and controlling performed to determine and accomplish stated objective by the use of human beings and other resources". Manajemen adalah proses yang berbeda antara perencanaan, pengorganisasian penggerakan dan pengawasan yang dilakukan untuk menentukan dan memenuhi tujuan yang telah ditetapkan melalui penggunaan sumber daya manusia dan sumber daya lainnya.

Rue \& Byar (2000, p.4) mendefinisikan manajemen sebagai sebuah bentuk kerja yang melibatkan proses koordinasi terhadap sumber-sumber daya yang ada dalam organisasi, seperti tanah, bangun-an, pekerja, dan modal untuk mencapai tujuan organisasi.

Manajemen pendidikan merupakan istilah yang dipakai dalam lingkungan pendidikan. Bush and Coleman (2000, p.4) menyatakan manajemen pendidikan ialah suatu praktik yang berfokus pada kegiatan organisasi pendidikan. Husaini Usman (2010, p.12) mendefinisikan manajemen pendidikan sebagai:

"seni dan ilmu mengelola sumber daya pendidikan untuk mewujudkan suasana belajar dan proses pembelajaran agar peserta aktif mengembangkan potensi dirinya untuk memiliki kekuatan spiritual keagamaan, pe- 
ngendalian diri, kepribadian, kecerdasan, akhlak mulia, serta keterampilan yang diperlukan dirinya, masyarakat, bangsa, dan Negara".

Dari teori dalam administrasi pendidikan Wayne K. Hoy dan Cecil G. Miskel (2001, p.3), berdasarkan karya Fred N. Kerlinger yakni teori manajemen pendidikan adalah seperangkat konsep yang saling terkait, asumsi, generalisasi yang secara sistematis menggambarkan dan menjelaskan keteraturan dalam perilaku dalam organisasi pendidikan. Definisi ini menyarankan tiga hal:

- Teori logis terdiri dari konsep, asumsi dan generalisasi;

- Fungsi utama dari teori adalah untuk menggambarkan, menjelaskan dan memprediksi keteraturan dalam perilaku;

- Teori heuristik adalah bahwa, dirangsang dan membimbing pengembangan lebih lanjut dari pengetahuan.

Dari pengertian manajemen pendidikan di atas, dapat diambil intinya, bahwa manajemen pendidikan itu merupakan keseluruhan proses dari kegiatan yang harus dilakukan menjadi tanggung jawab bersama untuk mencapai tujuan pendidikan. Dalam melaksanakan manajemen pendidikan mencakup kegiatan perencanaan, pengorganisasian, pengarahan dan pengawasan baik pada tingkat birokrasi pendidikan maupun di tingkat sekolah.

\section{Sarana dan Prasarana Pendidikan}

Dalam Ibrahim Bafadal (2004, p.2), perlengkapan sekolah atau juga sering disebut dengan fasilitas sekolah, dapat dikelompokkan menjadi: (1) sarana pendidikan; dan (2) prasarana pendidikan. Sarana pendidikan adalah semua perangkat peralatan, bahan dan perabot yang secara langsung digunakan dalam proses pendidikan di sekolah. Sedangkan prasarana pendidikan adalah semua perangkat kelengkapan dasar yang secara tidak langsung menunjang pelaksaan proses pendidikan di sekolah. Menurut Ibrahim Bafadal (2003, p.2) dalam Nawawi (1987) mengklasifikasikan menjadi beberapa macam sarana pendidikan, yaitu ditinjau dari sudut: (1) habis tidaknya pakai; (2) bergerak tidaknya pada saat digunakan; dan (3) hubungannya dengan proses belajar mengajar.

Sedangkan prasarana pendidikan di sekolah bisa diklasifikasikan menjadi dua macam. Pertama, prasarana pendidikan yang langsung digunakan untuk proses belajar mengajar. Seperti ruang teori, ruang perpustakaan, dan ruang laboratorium. Kedua, prasarana sekolah yang keberadaannya tidak digunakan untuk proses belajar mengajar. Contohnya adalah ruang kantor, kantin sekolah, ruang UKS, kamar kecil, ruang guru, ruang kepala sekolah, dan tempat parkir kendaraan.

\section{Manajemen Sarana dan Prasarana Pendidikan}

Manajemen sarana dan prasarana menurut Ary Gunawan (1982, p.114), menyatakan bahwa administrasi sarana dan prasarana pendidikan merupakan seluruh proses kegiatan yang direncanakan dan diusahakan secara sengaja dan bersungguh-sungguh serta pembinaan secara kontinu terhadap benda-benda pendidikan, agar senantiasa siap pakai (ready for use) dalam proses belajar mengajar sehingga PBM semakin efektif dan efisien guna membantu tercapainya tujuan pendidikan yang telah ditetapkan.

Manajemen sarana dan prasarana pendidikan merupakan salah satu bagian kajian dalam administrasi sekolah (school administration), atau adminstrasi pendidikan (educational administration) dan sekaligus menjadi bidang garapan kepala sekolah selaku administrator sekolah. Secara sederhana, manajemen sarana dan prasarana pendidikan dapat didefinisikan sebagai proses kerja sama pendayagunaan semua perlengkapan pendidikan secara efektif dan efisien (Ibrahim Bafadal, 2004, pp.1-2).

Dapat disimpulkan bahwa, manajemen sarana dan prasarana pendidikan bertugas mengatur sarana dan prasarana 
pendidikan agar dapat memberikan kontribusi secara optimal dan berarti pada jalannya proses pendidikan.

\section{Tujuan Manajemen Sarana dan Prasarana Pendidikan}

Menurut Ibrahim Bafadal (2003, p.5), secara umum tujuan manajemen sarana dan prasarana pendidikan adalah memberikan layanan secara profesional di bidang sarana dan prasarana pendidikan dalam rangka terselenggaranya proses pendidikan secara efektif dan efisien. Secara rinci tujuannya adalah sebagai berikut :

- Untuk mengupayakan pengadaan sarana dan prasarana pendidikan melalui sistem perencanaan dan pengadaan yang hati-hati dan seksama.

- Untuk mengupayakan pemakaian sarana dan prasarana sekolah secara tepat dan efisien.

- Untuk mengupayakan pemeliharaan sarana dan prasarana sekolah, sehingga keberadaannya selalu dalam kondisi siap pakai dalam setiap diperlukan oleh semua personil sekolah.

\section{Prinsip Manajemen Sarana dan Prasarana Pendidikan}

Dalam buku Manajemen Perlengkapan Sekolah, Ibrahim Bafadal (2003, pp.5-6), agar tujuan yang telah dikemukakan di atas dapat tercapai, ada beberapa prinsip yang perlu diperhatikan dalam mengelola sarana dan prasarana pendidikan di sekolah. Prinsip-prinsip yang dimaksud adalah (1) prinsip pencapaian tujuan; (2) prinsip efisien; (3) prinsip administratif; (4) prinsip kejelasan tanggung jawab; dan (5) prinsip kekohesian. Apabila kelima prinsip tersebut diterapkan, manajemen perlengkapan pendidikan bias menyokong tercapaiannya tujuan pendidikan.

\section{Proses Manajemen Sarana dan Prasarana Pendidikan}

Suatu proses merupakan suatu rangkaian aktifitas yang satu sama lainnya saling bersusulan. Proses adalah suatu cara sistematis untuk menjalankan suatu peker- jaan. Proses manajemen adalah suatu rangkaian aktifitas yang harus dilakukan oleh seorang manajer.

Dalam Ibrahim Bafadal (2004, p.6), proses manajemen sarana dan prasarana pendidikan di sekolah mencakup kegiatankegiatan pengadaan, pendistribusian, penggunaan dan pemeliharaan, inventarisasi dan penghapusan semua sarana dan prasarana pendidikan. Menurut Rahayu Islam (2009, p.42), kelima kegiatan itu dipersempit oleh Ali Imron, dkk. menjadi tiga kegiatan yaitu: pengadaan sarana dan prasarana, pemeliharaan sarana dan prasarana dan penghapusan sarana dan prasarana sekolah.

\section{- Pengadaan Sarana dan Prasarana}

Pengadaan sarana dan prasarana merupakan fungsi operasional pertama dalam manajemen sarana dan prasarana pendidikan persekolahan. Fungsi ini pada hakikatnya merupakan serangkaian kegiatan untuk menyediakan sarana dan prasarana pendidikan persekolahan sesuai dengan kebutuhan, baik berkaitan dengan jenis dan spesifikasi, jumlah, waktu maupun tempat, dengan harga dan sumber yang dapat dipertanggungjawabkan.

Untuk proses pengadaan sarana pendidikan, ada beberapa kemungkinan yang bisa ditempuh, yaitu (1) pembelian dengan biaya pemerintah, (2) pembelian dengan biaya dari SPP, (3) atau bantuan dari masyarakat lainnya. Berkenaan dengan pengadaan sarana dan prasarana pendidikan di sekolah ada tiga hal yang perlu dipahami yaitu: (a) perencanaan sarana dan prasarana sekolah; (b) cara pengadaan sarana dan prasarana sekolah; dan (c) administrasi sarana dan prasarana sekolah.

\section{- Pemeliharaan Sarana dan Prasarana}

Pemeliharaan sarana dan prasarana pendidikan adalah kegiatan untuk melaksanakan pengurusan dan pengaturan agar semua sarana dan prasarana selalu dalam keadaan baik dan siap untuk digunakan secara berdayaguna dan berhasil guna dalam mencapai tujuan pendidikan. 
Menurut Ibrahim Bafadal (2004, P.49), ada beberapa macam pemeliharaan sarana dan prasarana pendidikan di sekolah ditinjau dari sifat maupun waktunya.

Ditinjau dari sifatnya ada empat macam pemeliharaan sarana dan prasarana pendidikan di sekolah yang cocok untuk perawatan mesin, yakni: pemeliharaan perlengkapan yang bersifat pengecekan, pemeliharaan yang bersifat pencegahan, pemeliharaan yang bersifat ringan dan perbaikan berat.

Ditinjau dari waktu pemeliharaannya ada dua macam pemeliharaan sarana dan prasarana pendidikan di sekolah, yaitu pemeliharaan sehari-hari, seperti menyapu, mengepel lantai, membersihkan pintu dan pemeliharaan berkala, misalnya pengontrolan genting, pengapuran tembok.

\section{- Penghapusan Sarana dan Prasarana}

Ibrahim Bafadal (2004, P.62) mengemukakan bahwa secara definitif, penghapusan sarana dan prasarana pendidikan adalah kegiatan meniadakan barang milik lembaga (bisa juga milik negara) dari daftar inventaris dengan cara berdasarkan peraturan peraturan perundang-undangan yang berlaku. Sebagai salah satu aktifitas dalam pengelolaan sarana dan prasarana pendidikan, penghapusan bertujuan untuk:

- Mencegah dan membatasi kerugian yang lebih besar sebagai akibat pengeluaran dana untuk perbaikan perlengkapan yang rusak

- Mencegah terjadinya pemborosan biaya pengamanan perlengkapan yang sudah tidak berguna lagi

- Membebaskan lembaga dari tanggung jawab pemeliharaan dan pengamanan, dan

- Meringankan beban inventarisasi.

\section{Sekolah Menengah Kejuruan}

Pendidikan di Sekolah Menengah Kejuruan diharapkan mampu mewujukan gagasan mengembangkan karier sesuai dengan kebutuhan dunia usaha/dunia industri, mengidentifikasi sumber-sumber dunia kerja, mengidentifikasi peluangpeluang pekerjaan masa ini dan masa da- tang, meneliti peluang kerjaan, membandingkan range gaji dan kemanfaatannya, membandingkan profil jabatan, dan merekomendasikan kemampuan membuat lamaran pekerjaan scara baik dan benar. Pelaksanaan pendidikan menengah kejuruan akan mencapai sasaran jika menerapkan prinsip-prinsip bahwa pendidikan kejuruan efisien.

\section{Pendidikan Kejuruan}

Definisi pendidikan kejuruan di atas, sejalan dengan UU No. 20 Tahun 2003 tentang Sistem Pendidikan Nasional Pasal 22 yang mengemukakan tentang konsep pendidikan kejuruan bahwa: "pendidikan kejuruan merupakan jenjang pendidikan menengah yang bertujuan untuk mengembangkan kepribadian dan sikap pemahaman ilmu dan pengetahuan serta teknologi, apresiasi seni, dan ketrampilan hidup mandiri atau mengikuti pendidikan lebih lanjut".

Tujuan pendidikan kejuruan di Indonesia masih mendua, di satu sisi menyiapkan peserta didik memasuki dunia kerja, di sisi lain melanjutkan pendidikan ke tingkat lebih tinggi. Akibatnya lulusan sekolah menengah kejuruan tidak sepenuhnya memfokuskan perhatian untuk memasuki dunia kerja. Pendidikan kejuruan adalah pendidikan yang spesifik, demokratis, dapat melayani berbagai kebutuhan individu. Program pendidikan kejuruan tidak hanya menyiapkan peserta didik memasuki dunia kerja, tetapi juga menempatkan lulusannya pada pekerjaan tertentu.

\section{Karakteristik Pendidikan Kejuruan}

Menurut Rudy Fatchurrochman, (2011, p.32), pendidikan kejuruan mempunyai kekhususan atau karakteristik tertentu yang membedakan dengan subsistem pendidikan lain. Perbedaan ini tidak hanya dalam defenisi, struktur organisasi dan tujuan pendidikan saja, tetapi tercermin dalam aspek-aspek lain yang erat kaitannya dengan pengembangan kurikulum, yaitu:

- Orientasi pendidikannya (kinerja individu dalam dunia kerja); 
- Justifikasi untuk eksistensinya sesuai dengan kebutuhan nyata di lapangan;

- Fokus kurikulumnya pada aspek-aspek psi-komotorik, afektif dan kognitif;

- Tolak ukur kriteria keberhasilan tidak hanya di sekolah;

- Kepekaan terhadap perkembangan masyarakat/dunia kerja;

- Perbekalan logistiknya;

- Hubungan dengan masyarakat dan dunia usaha.

\section{Pembelajaran Praktik di SMK}

Pendekatan kurikulum berbasis kompetensi menekankan pada pembekalan penguasaan kompetensi kepada peserta didik yang mencakup aspek sikap, pengetahuan, keterampilan, dan tata nilai secara tuntas dan utuh. Sedangkan pembelajaran berbasis produksi, selain menekankan pada pencapaian kompetensi yang harus dikuasai, juga menekankan pada pemberian pengalaman belajar yang lebih bermakna melalui proses kerja yang sesungguhnya dan menghasilkan produk barang atau jasa sesuai dengan standar pasar yang layak jual.

Kurikulum Tingkat Satuan Pendidikan SMK Tahun 2006 menjelaskan bahwa proses pendidikan dan pelatihan di SMK dibagi dalam dua program, yaitu program produktif minimum $70 \%$ dan program teori maksimum 30\%. Dari pembagian persentase, hal ini mata pelajaran program produktif memiliki persentase paling besar (KTSP SMK 2006: 7-9).

Standar Sarana dan Prasarana SMK

Standar sarana dan prasarana Sekolah Menengah Kejuruan terdapat pada Peraturan Menteri Pendidikan Nasional Republik Indonesia Nomor 40 Tahun 2008 tentang Standar Sarana dan Prasarana untuk Sekolah Menengah Kejuruan/Madrasah Aliyah Kejuruan (SMK/MAK)

\section{Metode Penelitian}

Penelitian ini menggunakan penelitian kualiatif dengan menggunakan pendekatan deskriptif kualitatif. Alasan dipi- lih pendekatan deskriptif kualitatif adalah untuk mengetahui mengenai karakteristiknya, proses perubahan dan perkembangannya mengenai manajemen sarana dan prasarana di SMK N 1 Kasihan.

Teknik pengumpulan data yang digunakan adalah observasi, wawancara, dan studi dokumentasi. Instrumen yang digunakan untuk mengumpulkan data adalah lembar observasi, panduan wawancara, dan panduan dokumentasi. Keabsahan data diukur menggunakan triangulasi sumber.

Teknik pengumpulan data yang digunakan adalah observasi, wawancara, dan studi dokumentasi. Instrumen yang digunakan untuk mengumpulkan data adalah lembar observasi, panduan wawancara, dan panduan dokumentasi. Keabsahan data diukur menggunakan triangulasi sumber.

\section{Hasil Penelitian}

Manajemen Sarana dan Prasarana Mata Pelajaran Produktif

Manajemen sarana dan prasarana yang memuat proses pengadaan, pemeliharaan dan penghapusan, menurut Kepala Sekolah SMK N 1 Kasihan manajemen yang digunakan adalah manajemen standar, karena sekolah ini sudah menggunakan ISO 9001 : 2008 maka penyelenggaraannya juga menggunakan SOP (standart operating procedur) yang berdasarkan instruksi kerjanya "apa yang ditulis dikerjakan dan yang sudah ditulis dikerjakan" (Hasil wawancara dengan Kepala Sekolah, Drs. Sunardi, M. Pd pada tanggal 29 September 2012). Manajemen standar yang dikemukan kepala sekolah dapat dilihat pada Bukti Fisik Sasaran Mutu dan Dokumen Sistem Manajemen Mutu WKS Bidang Sarana dan Prasarana ISO 9001 : 2008.

Dalam Bukti Fisik Sasaran Mutu WKS Bidang Sarana dan Prasarana ISO 9001 : 2008 terdapat uraian kerja organisasi WKS Bidang Sarana dan Prasarana, persentase $91 \%$ sarana dan prasarana dapat 
dipergunakan dengan baik dalam Kegiatan Belajar Mengajar, 76\% kondisi sarana dan prasarana dalam keadaan baik, $94 \%$ tenaga pendidik (guru) memiliki pendidikan minimal S1 untuk menunjang program sertifikasi Guru, dan 97\% kehadiran tenaga pendidik setiap bulannya. Sedangkan pada Dokumen Sistem Manajemen mutu WKS Bidang Sarana dan Prasarana ISO 9001 : 2008 terdapat program kerja, rencana operasi, rencana pemantauan dan evaluasi serta hasil evaluasi/tindakan koreksi.

Manajemen standar terlihat pada kondisi rekapitulasi persentase inventarisasi sarana dan prasarana kegiatan belajar mengajar praktik sebesar $88 \%$ dalam keadaan baik serta kondisi rekalipitulasi persentase sarana dan prasarana sebesar 78\% dalam keadaan baik. Persentase ini menandai bahwa manajemen yang terdapat di SMK N 1 Kasihan dapat dikatakan standar karena kondisi sarana dan prasarana dalam keadaan baik, dengan adanya rencana pemantauan dan evaluasi yang dilakukan oleh WKS Bidang Sarana dan Prasarana.

\section{Pengadaan Sarana dan Prasarana}

Pengadaan sarana dan prasarana sekolah dilakukan untuk memenuhi kebutuhan sesuai dengan perkembangan program sekolah, menggantikan barang-barang yang rusak, hilang, dihapuskan atau sebab lain yang dapat dipertanggungjawabkan. Pengadaan sarana dan prasarana, dalam hal ini pihak SMK N 1 Kasihan melakukannya dengan cara yang hati-hati dan secermat mungkin, karena semuanya akan dipertanggungjawabkan kepada Dewan Sekolah. Untuk perencanaan pengadaan sarana dan prasarana, WKS Bidang Sarana dan Prasarana menerima masukan dari beberapa koordinator masing-masing unit tentang keperluan yang dibutuhkan yang sebelumnya dimusyawarahkan terlebih dahulu melalui sebuah perencanaan.

\section{Perencanaan Pengadaan Sarana dan Prasarana}

Cara yang dilakukan dalam perencanaan pengadaan sarana dan prasarana sekolah menurut WKS Bidang Sarana dan Prasarana dalam wawancara mengatakan bahwa pengadaan sarana dan prasarana dilakukan apabila terdapat peralatan yang rusak atau yang diajukan oleh guru dengan mengajukan usulan atau dengan perwakilan dari masing-masing koordinator pada rapat akhir tahun pelajaran atau sebelumnya diadakan analisa tentang kebutuhan peralatan pembelajaran dalam satu tahun ke depan.

Setelah melalui proses perencanaan pengadaan barang hal lain yang kemudian ditindaklanjuti adalah mengenai pengadaan sarana dan prasarana itu sendiri. Berikut ini perencanaan pengadaan sarana dan prasarana di SMK N 1 Kasihan tahun pelajaran 2012/2013.

Tabel 1. Daftar Rencana Pengadaan Sarana dan Prasarana Program Studi di SMKN 1 Kasihan Tahun Pelajaran 2012/2013

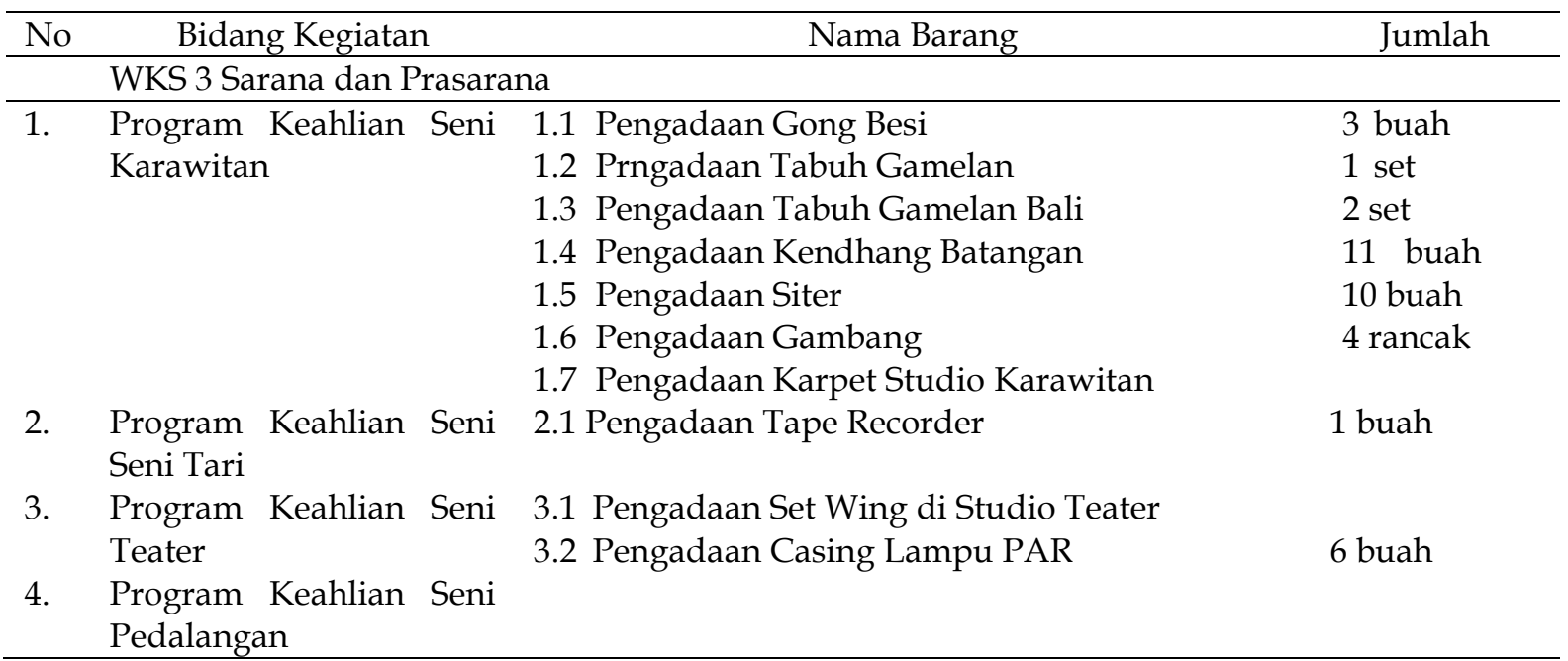


Pengadaan Sarana dan Prasarana

Pengadaan sarana dan prasarana pendidikan merupakan tindak lanjut dari perencanaan pengadaaan sarana dan prasarana yang telah ditetapkan dalam musyawarah atau yang sudah menjadi rutinitas. Pengadaan sarana dan prasarana di SMK N 1 Kasihan dilakukan dengan berbagai cara antara lain adalah sebagai berikut:

- Pengadaan barang dilakukan dengan cara membeli yang sifatnya rutinitas adalah kapur tulis dan spidol whiteboard untuk program keahlian Karawitan, dimana alat-alat ini merupakan peralatan yang habis pakai.

- Pengadaan barang yang bersifat jangka panjang atau peralatan yang tidak habis pakai yang pengadaannya dilakukan dengan cara membeli antara lain: gamelan, tape recorder, DVD, LCD proyektor, TV, VCD audio tari, OHP, dan alat audio lainnya yang berhubungan dengan bidang pertunjukan.

- Pengadaan barang dengan cara mendapatkan hibah atau hadiah antara lain bantuan dari pemerintah. Bantuan imbal swadaya dari dikdasmen dari Jakarta berupa transportasi Bus untuk bisa pentas keliling tanpa memperhitungkan masalah transportasi.
Administrasi Pengadaan Sarana dan Prasarana

Dalam administrasi pengadaan sarana dan prasarana, WKS Bidang Sarana dan Prasarana administrasi pengadaan dengan mencatat semua barang yang diterima ke dalam buku penerimaan, pembuatan kode barang yang terdapat pada KIB atau Kartu Inventaris Barang dan melaporkan setiap triwulan sekali.

\section{Pemeliharaan Sarana dan Prasarana}

Pemeliharaan sarana dan prasarana tidak mudah karena membutuhkan ketelatenan atau kecermatan dalam melakukannya. SMK N 1 Kasihan selalu memperhatikan dan memelihara sarana dan prasarana yang dimiliki karena sarana dan prasarana merupakan aset sekolah yang harus selalu dijaga keadaannya untuk menghindari hal-hal yang tidak diinginkan, pemeliharaan mutlak dilakukan, kebersihan harus terus dijaga pemeliharaan gedung juga harus demikian. Sarana dan prasarana SMK N 1 Kasihan dipelihara oleh orang-orang yang berkompeten dibidangnya. Pemeliharaan yang dilakukan dengan berbagai cara sebagaimana yang dikemukakan oleh WKS sarana dan prasarana yakni pemeliharaan dilihat dari waktu dan dilihat dari sifatnya.

Tabel 2. Daftar Pemeliharaan Sarana dan Prasarana Program Studi di SMKN 1 Kasihan Tahun Pelajaran 2012/2013

\begin{tabular}{llll}
\hline No & Bidang Kegiatan & Nama Barang & Jumlah \\
\hline & WKS 3 Sarana dan Prasarana & & \\
\hline 1. & Program Keahlian Seni Karawitan & 1.1 Melaras gender & 24 rancak \\
& & 1.2 Perawatan alat praktek & \\
2. & Program Keahlian Seni Seni Tari & 2.1 Tape Recorder & 12 buah \\
3. & Program Keahlian Seni Teater & 3.1 Kamera Ricoh & 3 buah \\
4. & Program Keahlian Seni & 4.1 Perawatan gamelan di ruang & \\
& Pedalangan & pedalangan & \\
\hline
\end{tabular}

Penghapusan Sarana dan Prasarana Pendidikan

Dalam penghapusan sarana dan prasarana di SMK N 1 Kasihan, dilakukan jika barang atau peralatan pembelajaran yang sudah tidak berguna seperti pecah atau rusak. Menurut WKS Bidang Sarana dan Prasarana, penghapusan pada tahun pelajaran ini belum pernah terjadi, tetapi pada tahun pelajaran yang lalu penghapusan terjadi terhadap alat transportasi berupa mobil dinas dikarenakan alat transportasi tersebut sudah tidak layak pakai. Pengha- 
pusan juga akan terjadi pada per-alatan pendidikan yang sudah tidak sesuai dengan perkembangan zaman antara lain mesin komputer yang lama diganti yang baru, mesin ketik manual dihapuskan dari daftar inventaris.

Sedangkan penghapusan sarana dan prasarana menurut pendapat WKS Bidang Sarana dan Prasarana yang mengatakan bahwasannya, penghapusan sarana dan prasarana dilakukan apabila terjadi kerusakan pada barang yang sudah tidak dapat dipakai lagi, akan tetapi sekolah ini belum melakukan penghapusan pada barang yang berharga. Karena sekolah belum pernah mengalami kerusakan barang ataupun kehilangan barang. Kalaupun hal tersebut memang terjadi maka akan dimasukkan pada inventaris penghapusan atau penghilangan barang.

\section{Simpulan}

Dari penelitian yang telah dilakukan di SMK N 1 Kasihan dapat diperoleh kesimpulan sebagai berikut ini.

Manajemen sarana dan prasarana yang digunakan oleh SMK N 1 Kasihan khususnya pada mata pelajaran produktif adalah manajemen standar yang menggunakan ISO 9001: 2008 dan penyelenggaraannya juga menggunakan SOP (standart operating procedur) sehingga pertanggungjawaban tentang proses manajemen sarana dan prasarana berdasarkan instruksi kerjanya. Manajemen standar yang dilakukan oleh sekolah melalui beberapa proses manajemen yaitu pengadaan, pemeliharaan dan penghapusan sarana dan prasarana.

Pengadaan sarana dan prasarana, dilakukan setiap akhir tahun dengan diadakannya musyawarah kerja RAKS. Menganalisis kebutuhan-kebutuhan yang diperlukan dengan menetapkan perencanaan untuk jangka satu semester atau satu tahun ke depan dengan memperhatikan dana yang dimiliki. Pengadaan barang dilakukan dengan cara membeli dan juga mendapatkan sumbangan baik itu dari pemerintah maupun dari iuran per bulan setiap siswa.
Proses pengadaaan barang yang sudah dilakukan, selanjutnya barang yang sudah dimiliki atau baru saja dibeli dilakukan pemeliharaan agar mendapatkan manfaat dari sarana dan prasarana yang dipelihara tersebut. Kemudian WKS Bidang sarana dan prasarana melakukan administrasi pengadaan dengan mencatat semua barang yang diterima ke dalam bu$\mathrm{ku}$ penerimaan, pembuatan kode barang yang terdapat pada KIB atau Kartu Inventaris Barang dan melaporkan setiap triwulan sekali. Dalam melakukan pemeliharaan sarana dan prasarana sekolah, dilakukan pemeliharana sehari-hari, melakukan pemeliharaan secara berkala, dan pemeliharaan yang sifatnya mencegah dari kerusakan.

Penghapusan sarana dan prasarana sekolah, sampai saat ini belum pernah melakukan penghapusan barang. Tetapi secara umum di antara barang-barang yang dimiliki ada yang sudah tidak dapat dipergunakan lagi atau tidak dapat memberikan manfaat terhadap jalannya proses belajar mengajar, maka barang tersebut dilakukan penghapusan atau penyingkiran. Penghapusan sarana prasarana yang dilakukan adalah terhadap barang-barang yang pecah atau barang yang tidak dapat digunakan lagi. Penghapusan dilakukan melalui prosedur pencatatan pada buku inventaris barang rusak kemudian dilaporkan pada WKS Bidang Sarana dan Prasarana.

Hasil penelitian ini menunjukkan bahwa pengadaan sarana dan prasarana, setiap warga sekolah mempunyai kewajiban untuk melakukan analisa kebutuhankebutuhan yang diperlukan dengan tetap memusyawarahkan kepada WKS Bidang Sarana dan Prasarana. Pemeliharaan terhadap sarana dan prasarana di SMK N 1 Kasihan, dilakukan menurut ukuran waktu dan ukuran keadaan barang dan dilakukan sendiri oleh pemegangnya/penanggungjawabnya atau memanggil tukang/ ahli servis untuk melakukannya atau membawanya ke bengkel servis. Dan dalam penghapusan perlu diperhatikan untuk WKS Bidang Sarana dan Prasarana yakni 
prinsipnya yang perlu diperhatikan ialah bahwa penghapusan barang tidak boleh menghambat kelancaran tugas sehari-hari dan perlu dipikirkan penggantinya.

\section{Daftar Pustaka}

Bafadal, Ibrahim. (2004). Manajemen perlengkapan sekolah. Jakarta: Bumi Aksara.

Bush, T. \& Coleman, M. (2000). Leadership and strategic management in education, (terjemahan oleh Fathuroji). Yogyakarta: IRCisoD.

Depdiknas. (2003). Undang-undang RI no. 20 tahun 2003, tentang sistem pendidikan nasional.

(2005). Peraturan pemerintah RI no. 19 tahun 2005, tentang standar pendidikan nasional.

(2006). Kurikulum tingkat satuan pendidikan sekolah menengah kejuruan edisi 2006.

(2008). Peraturan pemerintah RI nomor 40, tahun 2008, tentang standar sarana dan prasarana untuk sekolah menengah kejuruan/madrasah aliyah kejuruan (SMK/MAK).

(2012). Garis-garis besar prog-ram. Pembinaan SMK Tahun 2012 Jakarta: Direktorat Pembinaan Sekolah Menengah Kejuruan. Direktorat Jenderal Manajemen Pendidikan Dasar dan Menengah.

Fatchurrochman, Rudy. (2011). Pengaruh motivasi berprestasi terhadap kesiapan belajar, pelaksanaan prakerin dan pencapaian kompetensi mata pelajar-an produktif Teknik kendaraan ringan kelas XI: penelitian pada siswa kelas XI Teknik kendaraan ringan SMK N 1 Jatibarang, Kabupaten Indramayu, Provinsi Jawa Barat. Diambil pada tanggal 17 Januari 2012 dari http://repository.upi.edu/operator .upload/t_ptk_0908295_chapter2.p $\underline{\mathrm{df}}$
Gunawan, Ary. H. (1996). Administrasi sekolah (Administrasi Pendidikan Mikro). Jakarta: PT Rineka Cipta.

Hoy, W.K. \& Miskel, C.G. (2001). Educational administration. Theory, research, and practice. Sixth Edition. Library of Congress Catalog-in-Publication Data.

Islam, T.R. (2009). Manajemen sarana dan prasarana dalam meningkatkan mutu pembelajaran pendidikan agama Islam di SMA N 4 Malang. Diambil pada tanggal 11 September 2012, dari http://lib.uinmalang.ac.id//thesis/fulltext/05110224-rahayu-tahrirulislam.ps

Rue, L.W. \& Byars, L.L. (2000). Management: Skill and application. (8 $8^{\text {th }}$ ed.). Boston: Irwin McGraw-Hill.

Syaifabudi. (2003). Manajemen sekolah unggul. Diambil pada tanggal 15 Agustus 2012 dari http://www.Syaifabudi.org/manajemen.htm.

Terry, R.G. (1977). Principles of management. Seventh Edition. Illionis: Richard D. Irwin Inc.

Usman, Husaini. (2010). Manajemen: teori, praktek dan riset pendidikan (Edisi 3). Jakarta: Bumi Aksara.

Wuradji, (2006). Panduan penelitian survei. Yogyakarta: Lembaga Penelitian. Universitas Negeri Yogyakarta.

Zamtinah, (2000). Kompetensi standar lulusan SMK yang dibutuhkan industri. Jurnal Pendidikan, Lembaga Penelitian, Universitas Negeri Yogyakarta, 209, 0125-992X 